\title{
1. Introduction: the re-evolution of energy policy in Europe
}

\section{Israel Solorio Sandoval and Francesc Morata}

Putting more abundant energy at a cheaper price at the disposal of the European economies constitutes a fundamental element of economic progress.

Messina Declaration, 1955

The energy challenge is indeed one of the greatest tests of Europe.

Speech by EU Commissioner for Energy Günther H. Oettinger, on preparation of Energy Strategy 2011-2020, Brussels, September 2010

\subsection{INTRODUCTION}

To truly appreciate European integration development, it is crucial to understand the role energy has played (and has still the potential for) throughout the more than 50 years' history of this process. Indeed, it is hardly possible to explain the origins of the European Union (EU) without considering what happened in Europe just after the end of World War II (Lucas, 1977). Starting with the establishment of the European Coal Organisation (ECO) in 1946 and then the Organisation for European Economic Co-operation (OEEC) in 1948, energy was a cornerstone of European integration. The rationale for establishing the first Community organization in 1951, the European Coal and Steel Community (ECSC), lay explicitly with the energy-related challenges that Europe had to face during those years. A similar motivation lay behind the creation of the European Atomic Energy Community (Euratom) in 1957, with both the latter and the ECSC constituting the basic pillars of the European Economic Community (EEC). Thus, it is accurate to argue that energy is not only deeply rooted in European construction, but that it has been in itself with more or less success - a driver of integration.

That said, it is fairly paradoxical that the integration process has never developed so far as to lay the foundations for a fully fledged and coherent common energy policy, which has instead become one of the weakest policy areas to date. During the 1980s, energy policy was considered a 'spectacular failure' of integration (Andersen, 2000). However, this condition has been 
gradually changing. Even when the EU's participation in energy policy really took off in the 1990s by means of contiguous areas (primarily environment and liberalization of the internal market), it was not until recently with the Lisbon reform and the Treaty on the Functioning of the European Union (TFEU) that the formal barriers that hindered Brussels's action in this policy area were finally broken down. The overriding result is that energy now pertains formally to the 'family' of EU policies.

By building a forward-looking 'European energy policy' ${ }^{1}$ (the term is used throughout this book to refer to the coordinated efforts between the EU and its member states in this policy field), the EU is preparing the ground to face twenty-first-century global challenges such as climate change and the exploding demand for energy (Pielbags, 2009, p. 3). For this, the EU has arranged what are meant to be their policy goals in the field (that is what we refer throughout this book as the 'energy trinity'): (1) increasing security of supply; (2) ensuring the competitiveness of European economies and the availability of affordable energy; (3) promoting environmental sustainability and combating climate change (Council of the European Union, 2007, p. 11). Energy policy is no longer a matter exclusive to the national administrations, as nowadays Brussels performs an active, although still limited, role in this field.

This transition in the governance of energy policy in Europe is reflected in the chapter 4 of the TFEU, where energy appears as a 'shared competence' between the EU and its member states - as in the case of the internal market, the environment and the trans-European networks (art. 4.2, TFEU). This effort to better coordinate actions in the energy field is reflected in art. 194 of the TFEU on energy, which argues as follows:

In the context of the establishment and functioning of the internal market and with regard for the need to preserve and improve the environment, Union policy on energy shall aim, in a spirit of solidarity between Member States, to:

(a) ensure the functioning of the energy market;

(b) ensure security of energy supply in the Union;

(c) promote energy efficiency and energy saving and the development of new and renewable forms of energy; and

(d) promote the interconnection of energy networks. (art. 194.1, TFEU)

In this regard, in spite of the 'misleading debut' of energy in the European integration (Buchan, 2009, p. 6), '[t] oday's leaders have [finally] come back to the philosophy which Europe started off with in the 1950s - namely that the best way to deal with energy challenges is European cooperation' (Oettinger, 2010b). After decades of boosting cooperation in the energy field by means of alternative paths (see Lucas, 1977; Matláry, 1997), nowadays the European energy policy can rely on a stronger legal framework in order to pursue the energy trinity. It is notable that even though this article refers to objectives 
previously contained in the Treaty establishing the European Community (TEC), these objectives were actually disseminated throughout the treaty according to distinct policy areas (for example internal market or environment) (Zapater, 2009).

The fact that these energy policy goals are now laid down in the Lisbon Treaty is aimed at facilitating the advancement towards policy coherence. Indeed, the expected outcome of this new governance framework is to reduce existent contradictory signals between the EU and its member states' policies together with the trade-offs derived from the energy trinity and the matching areas of the European energy policy (internal market, external relations and environmental/climate protection), which is one of the biggest concerns for the EU. As pointed out by David Buchan (2009, p. 16), '[i]ndeed it is ironic that Brussels should devote so much rhetoric denying the existence of such conflicts when it spends so much time actually dealing with them'.

While this governance framework presents new opportunities to the EU, it must be clarified that there is still an essential constraint to its performance. This critical limit stems from the member states' 'right to determine the conditions for exploiting its energy resources, its choice between different energy sources and the general structure of its energy supply' (art. 194.2, TFEU). To be clear, this exception, which derives from an identical one imported from the environment chapter, leaves a narrow yet significant space that protects member states' sovereignty in a core aspect: the energy supply structure. The result is that 'the EU has no power over member states' energy mix, depletion policy or taxation' (Buchan, 2009, p. 9).

Therefore, five main aspects of the emergent European energy policy need to be emphasized in relation with the European integration process:

1. For now, it is the coordinated action both of the EU and of its member states that defines the European energy policy.

2. Its governance essentially relies on the cooperation between the EU and its member states.

3. It is still 'a work in progress'.

4. Its final outcome is uncertain.

5. Consequently, it is still far from being a common policy.

This unprecedented period for energy policy in Europe has drawn attention to EU performance in this policy area for the first time (traditionally under the member states' control, except for the deregulation policy and the Euroatomrelated issues). Against this backdrop, the argument of Janne Matláry sounds fairly outdated: '[e]nergy policy in the European Union has never been one of the main areas of integration, and for this reason this policy area has attracted little scholarly attention among analysts of the EU' (Matláry, 1997, p. 1). 
Today, energy policy is a 'hot topic' in the EU's political agenda, also attracting the attention of scholars. The growing number of articles and academic works dealing with energy policy in Europe is proof of this trend (for example Buchan, 2009). Yet there is a lack of understanding of the effects this process is producing, especially with regard to the 'green component' of the European energy policy (see below).

In spite of the current financial and economic crisis, the energy policy area remains one of the key concerns both at European and national levels. Since energy is the 'blood' of modern societies and the whole economic and social well-being of the European peoples and European industry relies on safe, secure, sustainable and affordable energy (European Commission, 2011a, p. 2), there are those in Europe who argue that energy policy is to be 'the next great European integration project' (European Commission, 2011b, p. 2). The pressing importance of current challenges such as climate change and energy security has made the creation of European energy policy an essential prerequisite for the construction of the Europe of the twenty-first-century, and the European institutions have therefore called for a 'revolution in the energy systems' to face the challenging global context that hastens the decarbonization of the European economy (European Commission, 2011b, p. 1).

\subsection{ENERGY AND ENVIRONMENT: AN OPEN-ENDED HISTORY?}

To begin with, we must stress that what we are now witnessing is the realization of a process that entailed the progressive transition of governance towards the EU. In the words of David Buchan (2009, p. 7), energy policy in the EU is characterized by an 'organic' growth, where 'policymakers borrowed legal competence from the economic and environmental parts of the EU treaties in order to justify proposing and passing energy measures'. Hence, it is not surprising to notice that a peculiarity of the emergent energy policy in Europe is that the EU already possesses a significant number of instruments for attaining its energy trinity goals (see Chapter 6 by Solorio and Zapater).

There is a broad consensus regarding the fact that the environmental concerns of the energy chain have been some of the most significant drivers to influence EU energy policy (Damro et al., 2008; Buchan, 2009; Solorio, 2009, 2011). The integration between environment and energy policies has been an outstanding platform upon which the EU has influenced energy governance, a process that gathered pace as the 'antidote' to global warming concerns (Collier, 2002, p. 177). Climate change has been a key element in leading the EU to debate its energy policy at a more practical level (Piebalgs, 2009), and the link between environment and energy policies has gradually transformed 
the energy policy in Europe (Buchan, 2009). On the one hand the integrated approach between climate and energy policies is one of the most innovative features, adopted after the 2007 spring European Council. On the other, the 2009 Climate and Energy Package is considered the flagship instrument of the EU's forward-looking perspective on a sustainable energy model (Oberthür and Pallaemarts, 2010).

While there are few doubts regarding the energy chain's environmental concerns as a driver behind the European energy policy (that is behind the cooperation in the energy field between the EU and its Member States), there is still a lack of clarity as to how the intrinsic relationship between both policies has transformed and ultimately shaped energy policy in Europe. Accordingly, even when the environment-energy relationship has received considerable political and scientific attention (for example Collier, 1994, 1997, 2002), what we are still missing is a picture to help us understand how the increasing proximity of both policies has contributed to the transformation of energy policy.

Broadly speaking, we can distinguish four phases through which the relationship between both policies has passed and which explain how the progressive integration ${ }^{2}$ of environmental concerns has influenced European energy policy construction.

\subsubsection{Phase 1: Environmental Awakening}

From its early beginnings, European integration has demonstrated a propensity to react to emergent problems (Jordan et al., 1999). With the growing concern over environmental issues in the 1970s, the Community did not hesitate to focus on the ecological impact of the energy chain. The Commission's reflections as well as the Council's resolutions reflected the reality of increasing environmental awareness (for example Commission of the European Communities, 1972, 1974; European Council, 1974, 1975). The institutional flexibility allowed environmental issues to become one of the earliest and most remarkable goals of the free movement of goods policy (Pollack, 1994, p. 124). However, the oil crisis of the 1970s contributed to making energy security one of Europe's paramount policy goals (Natorski and Herranz-Surrallés, 2008). This scenario increased the necessity of formulating and developing policies together in order to tackle the energy problems. Specifically regarding the environment, the Council (1975) provided the following statement:

[I]t is the duty of the Communities and the Member States to: (a) take environmental protection requirements into account in all energy policy strategy by taking effective measures. (Council of the European Communities, 1975) 
The recognition of environmental policy integration (EPI) as a policy objective was translated into a considerable number of environment-related measures and recommendations. On the energy efficiency side, there were numerous acts such as the action program on the rational use of energy and the recommendations on the energy consumption of road vehicles and on the rational use of electrical household appliances. Resolutions were also adopted on setting a short-term target for the reduction of oil consumption and for energy savings. On the other hand the development of renewable energy sources (RES) was delayed, given the immediate need to solve the supply problems (Twidell and Brice, 1992). Thus the Community's activities were limited to granting financial support for projects to exploit alternative energy sources.

This first phase was characterized by an increasing awareness of environmental issues within Europe and the very first reactions in this regard. EPI began to be recognized as a policy objective in energy policy-making, and the Community adopted a considerable body of legislation consisting of EPIrelated instruments years before the Single European Act (SEA). The Commission's main success was to bring energy issues back onto the European agenda and to trace a path that in the following years appeared to be a useful driver for the evolution of energy governance: the environmental policy.

\subsubsection{Phase 2: Environmental Formal Competence}

The year 1986 was of great significance for European integration as well as for EPI issues. The main shift upon the SEA's arrival came through internal market performance (McGowan, 2008) as well as the institutionalization of other significant areas such as environmental policy. The new environmental policy emerged with the task of protecting the environment 'through the prudent and rational utilization of natural resources' such as oil products, natural gas and solid fuels (Article 191, TFEU). The Community environmental policy was supported by two particular features from the start: (1) its success in terms of expansion, and (2) its efforts towards integration in other policies, mainly in the energy field.

Regarding its expansion, this can be measured by the number of legislative acts adopted, as well as the successive governance modifications in the following treaty revisions. With regard to integration, it is worth commenting that the new competence emerged nearly parallel with the fourth Action Programme (1987-92), which declared that the 'integration of the environmental dimension in other major policies will be a central part of the Commission's efforts' (Owens and Hope, 1989, p. 97). The initial years of environmental competence were characterized by a lack of remarkable results in energy policy, 
perhaps with the exception of the large combustion plant directive. However climate change emerged as a hot topic at the international level, which proved beneficial for the relationship between energy and environment (Damro et al., 2008). Since the first EU target for stabilizing carbon dioxide emissions was adopted by the Joint Council of Energy and the Environment in October 1990 (Skjaerseth, 1994), the European climate policy has become increasingly intertwined with energy policy. This second phase led to the institutionalization of environmental policy as a path for intervening in the energy field. The results of this second phase became more evident in the following years.

\subsubsection{Phase 3: Formal Integration}

EPI was legally codified by the Maastricht Treaty in 1992 and incorporated into TEC art. 6 (art. 11, TFEU), which contains the integration principle as a core EU objective (Lenschow, 2002). It recognized that the environmental protection requirements must be integrated into the definition and implementation of the Union's policies and activities, in particular with a view to promoting sustainable development. In parallel with these governance changes, climate change placed more pressure on the integration process of both policies. While this issue has moved to the mainstream of the international political agenda, Europe has also accelerated efforts to reduce global warming, thus improving its energy consumption practices (Henningsen, 2008; Solorio, 2009, 2011)

With the intention of presenting the European Community negotiators with strong arguments for the Rio Conference in 1992, the Commission proposed a 'Climate Package' for the first time that included a directive proposal on renewable electricity (RES-E); regulatory measures in the field of efficiency and energy savings, and a tax on energy-using products (Skjaerseth, 1994). However this package was diluted by the Council, which ultimately adopted pilot programs such as ALTENER and SAVE and excluded the possibility of taxation on energy use and a regulatory framework for RES-E (Collier, 1997). Nevertheless this involved the development of the first Community strategy to fight climate change in the early 1990s, the emergence of the climate policy to the core of the EU agenda and the creation of a new stage for EPI issues (Andersen, 2000).

Given the growing awareness of climate change, it is understandable that limiting carbon dioxide emissions by improving energy efficiency was a significant step forward. The Directive SAVE (closely related to the homonym program) emerged with the intention of drawing up and implementing programs in fields related to energy efficiency. Regarding RES, the Commission decided to boost their development with the Green Paper of 1996 on RES, a document that provided the basis for the White Paper in this area. 
The initiation of the so-called 'Cardiff Process' in 1998 represented a step forward to the practical application of EPI, calling to Council formations to prepare strategies and programs focused on integrating environmental considerations into its own policies (See Chapter 2 by Adelle et al.). Regarding energy, the Commission upheld that 'given the important impact on the environment, environmental integration cannot be achieved without adapting energy policy' (European Commission, 1998, p. 3). This way, energy efficiency and RES came to form the cornerstone of a sustainable energy system (Collier, 2002). Soon new environmental measures were adopted at the EU level, such as the RES-E Directive, and the biofuels Directive (see Chapter 3 by Knudsen). Moreover, once the Kyoto Protocol was ratified in 2002, the adoption of concrete measures to fight against climate change accelerated. Soon after, the directive establishing a scheme for greenhouse gas emission allowance trading within the Community was adopted and a consensus was even reached to adopt a measure restructuring the Community framework for the taxation of energy products and electricity. EPI's third phase was characterized by a double impetus to its integration within energy. On the one hand, the consolidation of environmental governance facilitated its influence in energy. On the other hand, climate change as an outstanding issue in international as well as in European politics sped up this process (Damro et al., 2008).

\subsubsection{Phase 4: European Energy Policy Emergence}

In 2005, the EU began a new stage in its climate change program in order to prepare a mid- and long-term strategy to confront this challenge. In this context, the European Council perceived 'the need to demonstrate that the EU's commitment to meet Kyoto ... is practical and not just a paper one' (Piebalgs, 2009, p. 2). In response, the Commission began pushing forward the energy debate with the paramount goal of laying down the foundations of a new energy policy of global character as an indispensable step towards effectively tackling climate change (European Commission, 2006, 2007).

The first step was the Green Paper entitled A European Strategy for Sustainable, Competitive and Secure energy, in which the Commission put forward concrete proposals for implementing a European energy policy (European Commission, 2006). In the following year, 2007, the Commission launched a strategic review of the current energy challenges as a guide to Europe's energy policy, in which the 'triple twenty' (RES, energy efficiency and greenhouse gas emissions reductions) were specified as a necessary goal to limit climate change. In this document, the Commission argued that '[m]eeting the EU's commitment to act now on greenhouse gases should be at the centre of the new European Energy Policy' (European Commission, 2007).

As a turning point, the 2007 spring European Council highlighted the 
Action Plan (2007-2009) Energy Policy for Europe 'as a milestone in the creation of an Energy Policy for Europe and as a springboard for further action' (Council of the European Union, 2007, p. 13). An imperative goal was set to achieve integration between climate and energy policies (Council of the European Union, 2007, p. 11). The European Council also recognized the importance of EPI by stating that 'a substantive development of energy efficiency and of renewable energies will enhance energy security, curb the projected rise in energy prices and reduce greenhouse gases emissions' (Council of the European Union, 2007, p. 20).

Responding to the Council's move, the Commission launched the Communication '20 20 by 2020: Europe's Climate Change Opportunity' on January 2008. The Commission proposed a set of measures 'designed in a way so that they are mutually supportive', in order to translate 'political direction into action' (European Commission, 2008). The economic crisis was certainly an added obstacle during the legislative process. However, after the hard intergovernmental negotiations, the Climate and Energy Package became law in early 2009. The package comprises four main measures: (1) a revision of the Emissions Trading System (EU ETS); (2) an 'Effort Sharing Decision' governing emissions from sectors not covered by the EU ETS, such as transport, housing, agriculture and waste; (3) binding national targets for RES; and (4) a legal framework to promote the development and safe use of carbon capture and storage (see Chapter 5 by Fischer). With all these measures, it represents the most concrete expression of the new European energy policy and the most convincing proof that the win-win solutions between energy and environment are more than possible.

When the internal dimension of the EU energy policy has apparently been moving easily towards a more sustainable approach, the picture regarding its external dimension is dominated by a great concern for exporting its market model and securing energy supply. The European Commission has often emphasized that 'the same collaboration and common purpose that has led to the adoption of the EU's headline energy and climate targets is not yet evident in external energy policy' (European Commission, 2011a, p. 17). However, in order to pursue this paramount goal regarding the external dimension of its energy policy, the EU has to 'face up to' its own nature. In other words, given that 'EU external energy policy stems from the complex and hybrid nature of the European integration' (Belyi, 2008, p. 203), the goal of a single approach and speaking with a single voice is an overarching need that has been a constant cause of frustration in Brussels.

The EU Commissioner for Energy, Günther Oettinger, recently stated that 'the EU still hesitates to commit itself to a coherent and common external voice' (Oettinger, 2010a, p. 3). In this sense, it is essential to acknowledge that the 'Lisbon Treaty will lend the EU more weight and a clearer profile in its 
external relations' (Müller-Kraenner, 2010, p. 2). A new window of opportunity has been opened for pulling together a broad range of policies, touching upon cooperation with third countries, humanitarian aid, common commercial policy, development, and cooperation policy and, needless to say, security and foreign policy, under the broader umbrella of energy policy. Nevertheless, it is still too early to predict how these changes in the EU's external profile will impact on policy-making in the energy field.

To sum up, from this historical review there are at least three main issues to note regarding EPI in energy and the development of the European energy policy. First of all, there is a clear continuity of the environmental component as a result of sector-specific actions within energy, encouraged mainly in the framework of the European fight against climate change. Second, the wider concept of EPI has, at least within energy policy, been centered on the environmental subsector of climate policy (see Chapter 2 by Adelle et al.). Third, after this historical review the link between the environmental policy development impelled by EPI and the Europeanization of energy governance remains clearer (that is facilitating the emergence of the European energy policy) (see Chapter 6 by Solorio Sandoval and Zapater). In this context, the former commissioner on energy, Andris Pielbags, seems to have been correct in defining the EU's shift in energy policy as the 'third industrial revolution' (Pielbags, 2009, p. 5).

\subsection{AIMS OF THIS BOOK AND OVERALL ANALYTICAL FRAMEWORK}

While the past years have contemplated an unprecedented development of the energy policy at the European level, the understanding of this process has lagged behind. Alongside the scarce literature on this emergent policy, there is also a gap regarding the attention paid to its different components. On the one hand, too much interest has been paid to the member states' actions, deflecting the EU efforts to boost European coordinated action in this field. On the other, there is certainly a mismatch between the valuable debate that certain dimensions of energy policy - namely, energy security and the market and competition framework - have triggered and the neglect of its environmental and climate change dimensions (although the several attention paid to the EU's climate policy). This book is intended to highlight the significance of environmental policy concerns, instruments, and objectives vis-à-vis the competing security and market dimensions in order to achieve an all-embracing EU energy policy perspective for the future.

How to understand in depth the EU energy policy and its 'green component'? As seen with the historical analysis presented above, EPI is a useful tool 
for understanding the closeness between energy and environmental policies in the EU. It is known that the concept of EPI as a principle of environmental policy stems from the wider theoretical concept of sustainable development. There are two fundamental ways of looking at EPI: one based on rationality and the effectiveness of policy-making, the other on normative and principled assumptions. Irrespective of the chosen approach, it is worth reminding that '[e]nergy presents a major challenge for the concept of integration ... because of its political and economic significance and because of the complexity of energy-environment interactions' (Owens and Hope, 1989, p. 97). Accordingly, this book copes with the matter of integration between environment and energy policies (see Chapters 2 and 3). Following the challenge to undertake the European energy policy, Europeanization is an indispensable analytical instrument to penetrate in the 'adaptive process triggered by European regional integration' (Vink and Graziano, 2007, p. 7). The Europeanization of energy policy governance has radically changed its conception. What have been the main changes and driving forces behind this process? This book has been written to tackle this issue. Last but not least, the EU not only has the obligation to go forward in its effort to integrate climate and energy policies, but also has to confront the apparent disassociation between what the EU is doing at home and the bulk of its external relations. In this sense, external governance and/or external Europeanization are by far the most useful analytical devices to approach the EU external relations regarding energy policy and the promotion of a sustainable energy system. In sum, the chapters included here move between different approaches to EPI, Europeanization and external governance in order to carry out the overriding task of explaining the dynamics affecting both the internal and the external dimensions of European energy policy.

This introductory chapter proposes a three-step model of 'green Europeanization' for energy policy (Figure 1.1) as an explanatory tool for contextualizing the changes that have occurred in European energy policy. Our model here attempts to illustrate: (1) how energy governance was Europeanized before formal competence was granted by means of environmental performance (a process illustrated in the first part of this book) and (2) the emergence of the EU as a 'green-model' exporter referring to energy policy (a process captured in the second part).

As shown before, the environmental concerns regarding the energy chain were a useful 'excuse' in order to facilitate Community intervention. This is the first step of our model: EPI in energy. Just after the oil crisis shocked Europe in the 1970s the European institutions led by the Commission began to facilitate the 're-entry' of energy onto the Community's political agenda (Andersen, 2000, p. 2). Certainly energy security was the main concern 


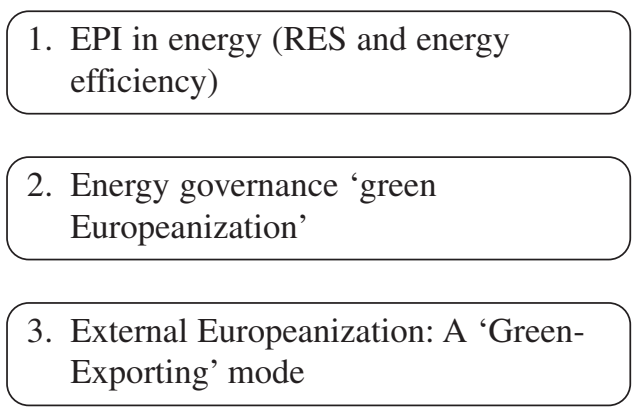

Source: Own interpretation.

\section{Figure 1.1 'Green Europeanization' model.}

between the energy policy goals at that time (Natorski and Herranz-Surrallés, 2008, p. 75). It was also undeniably the positive step that opened the door to Community participation in energy policy and the adoption of a number of Regulations - primarily concerning energy efficiency but also trying to boost RES at the European level.

The awakening of environmental concerns regarding the energy chain (and the need for urgent action) led eventually to the institutionalization of EPI as a concept guiding EU environmental policy-making. Of particular note here is the fact that when EPI generated enough consensus regarding the urgency of greening the energy policy (Collier, 2002), the number of strategies and choices to make integration a reality became considerably more widely debated. Against this background we need to clarify that even though nowadays EPI is largely considered as a 'dead process' in EU policy-making, its heritage in energy policy is self-evident (see Chapter 2 by Adelle et al., Chapter 3 by Knudsen and Chapter 6 by Solorio Sandoval and Zapater).

The analysis of the greening of energy policy has been well documented by Ute Collier in her publications on EPI (Collier, 1994, 1997, 2002). Nevertheless, there is a 'black hole' in the understanding of how the increasing proximity between both energy and environment has contributed to Europeanizing energy policy in Europe. This represents the second step of our model: the'green Europeanization' of energy policy. In this context, it is noticeable that although the Europeanization research agenda recently received considerable attention in European studies (Bulmer, 2007), energy policy has been a largely neglected area. It is certainly reasonable to acknowledge that numerous elements of energy policy have been examined during this period of expansion of the Europeanization research agenda. However, they have frequently been limited to a sector-based perspective and have by no 
means covered the broader picture of energy policy. In other words, if this sector-based perspective is required, given the role of energy in European integration, these studies have yet to succeed in expanding the Europeanization approach to overall energy policy because of their research foci.

Research concentrated on the Europeanization of the internal energy market has attracted most of the attention (McGowan, 2008). It is possible to find earlier examples, such as the study by Andersen (1999) on natural-gas liberalization, the work of Eising and Jabko (2001) on the changing objectives of the French energy policy as a result of the market liberalization negotiations, the well-known publication by Levi-Faur (2002) on the Europeanization of the electric and telecommunications regime and the research of Humphreys and Padgett (2006) on globalization, EU and domestic governance, as well as other relevant works (Jordana et al., 2005; Bartle, 1999, 2002). Oddly though, despite the considerable political attention to climate change in the EU (Damro et al., 2008), it is hard to find studies linking the environmental performance of the EU and the Europeanization of energy policy (Solorio Sandoval, 2009, 2011). Such a link therefore provides an emerging research agenda, which is addressed in Part I of this volume.

One of the main tasks this book attempts is to analyze how the EU governance system has been centralizing many policy-making activities regarding energy in Brussels, while relying on national administrative actors for implementation (Knill and Lenschow, 2005). However, the 'adventure' of analyzing EU influence on energy policy entails certain risks. First of all, this task involves considerable risks inherent in the application of the Europeanization framework, which has been quite 'contested as to its usefulness for the study of European politics' (Vink and Graziano, 2007, p. 3). Second and as already mentioned, our research topic distinguishes itself from other policy fields since the Europeanization of energy governance has been mainly driven by competences in related areas. Hence it becomes necessary to follow the 'green Europeanization' model in order to understand the indirect Europeanization of energy policy through EU environmental performance.

When approaching the Europeanization of energy policy, a fundamental step towards understanding it is to categorically separate the 'process in which countries pool sovereignty' from what follows 'once EU institutions are in place and produce their effects' (Radaelli, 2000, p. 6). In other words, it is essential to identify the limit between Europeanization and political integration. Nevertheless the boundary between both can become blurred by the fact that Europeanization has a dual function: (1) 'as an independent variable in domestic politics' and (2) 'as the processes by which domestic structures adapt to European integration' (Caporaso, 2007, p. 27). In particular, this book is interested in exploring function (1). The goal pursued is to understand the European energy policy as a transformation variable. However, it is also true 
that a key element in this process is to shed light on the interaction between Europeanization and political integration, and this is therefore a principal task throughout the entire book.

While the first part of this book is centered on the European energy policy as a variable of change for its member states, the second is dedicated to understanding the EU's role as an exporter of its energy model - that is external Europeanization, the third step of our model. The bulk of literature that focuses on the export of ideas, rules and norms beyond EU borders has grown significantly in recent years (for example Lavenex and Schimmelfenning, 2009; Barbé et al., 2009). Energy being a core interest of the EU's external policy, it has occupied an increasingly central place on the agenda in this particular case. As put forward by Sandra Lavenex and Adam Stulberg (2007, pp. 135-36),

[h]arbouring no illusions that energy security can be attained through self-sufficiency, expanding alternative (renewable and sustainable) energy resources, or managing internal consumption alone, the EU has placed priorities on managing the diversification of external supply and market stability in Europe.

Paradoxically, in this sense, it is remarkable that even when climate change has been a main concern of EU external action (Wurzel and Connelly, 2010), most of the literature referring to EU external governance has focused on the projection of the internal energy market rules (see Escribano, 2010; Herranz Surrralés and Zapater, 2010), on the geopolitical dimension of EU energy policy (see Correljé and Van der Linde, 2006) and on issues concerning the security of supply (see Umbach, 2010).

Contrary to this tendency, this book stems from the understanding that the EU's policy actors have sought climate change not only as a challenge but also as an opportunity in order to become an exporter of its energy model with the expected political and economic advantages (Wurzel and Conelly, 2011). In this context the third step of our 'green Europeanization' model focuses on the EU's foreign behavior and the emergent role as an exporter of its 'greenenergy' model. That is to say, the second part of this work focuses on the neglected side of external European energy policy: the promotion of a sustainable energy model beyond European frontiers. This book also serves as a piece of evidence on how the increasing concern for energy security and/or the internal market rules in the external dimension of the European energy policy affect the promotion of a 'green-energy' model abroad.

To sum up, this book aims to contribute to the scarce literature regarding the European energy policy by putting the emphasis on its environmental component (that is by highlighting the significance of environmental policy concerns, instruments, and objectives vis-à-vis the competing security and market dimensions in order to achieve an all-embracing EU energy policy 
perspective for the future). Finally, moving beyond the mere descriptive analysis, the authors contributing to this volume have been encouraged to emphasize the green element of the European energy policy (in its internal as well as in its external dimension), a frequently neglected yet essential element for building a forward-looking energy policy for twenty-first-century Europe.

\subsection{STRUCTURE OF THE BOOK}

This volume is in two main parts covering the internal and the external dimensions of the European energy policy, besides the introductory and conclusive chapters. In Chapter 2, Camilla Adelle, Duncan Russel and Marc Pallemaerts touch upon the sensitive issue of the integration in the EU of policies on energy, on climate change and on the environment in general. The chapter draws on the longer-standing difficulties of translating the concept of EPI in policy and administrative terms. While climate change challenges stress the need to improve the existing cross-sectoral coordination mechanisms or to introduce new structures and procedures, the fact remains that generally speaking, effective linkages are still missing both at the EU and the domestic level. The chapter focuses on the European Commission's strategies as regards climate and energy policy. Based on the evaluation framework designed by the EEA, it both assesses the progress achieved and also surveys the shortcomings still hampering the integration of climate change issues into the energy sector.

Starting with the theoretical implications of EPI for European energy policy from the dual horizontal (cross-sectoral policies) and vertical (multilevel governance) perspective, in Chapter 3 Jørgen K. Knudsen examines how EPI has been incorporated into the promotion of RES in the EU. The empirical analysis of the implementation process in the Nordic countries (Denmark, Finland, Norway and Sweden) provides an assessment of the extent to which EPI and RES-E have been connected and followed up in these states. Despite a high level of market integration in the electricity sector among the four countries, both domestic contextual and institutional specificities reveal different approaches to EPI's effective implementation. The chapter concludes with a discussion about the potential of EPI for contributing to a stronger common EU RES policy.

In Chapter 4 Per-Olof Busch and Helge Jörgens put the spotlight on the diffusion of RES policies in the EU. More precisely, their contribution attempts to assess the impact of EU programs on the degree of convergence achieved in this field by the member states as a form of Europeanization (that is 'green Europeanization'). Drawing on an analytical scheme based on three classic modes of international policy coordination (cooperation, coercion and diffusion), the authors examine the cross-national spread of support schemes 
for electricity generation from RES sources from 1988 to 2005. These consist of feed-in tariffs and green certificate systems. The analysis highlights the interactions between the domestic implementation of these incentives and the mechanisms of Europeanization promoted by the European Commission.

In Chapter 5, Severin Fischer also applies the Europeanization approach to the issue of carbon capture and storage (CCS). The author stresses the high expectations raised by this new technology, especially in some coal-producing countries, but also the uncertainties about the environmental risks that it may entail. The chapter examines in depth the complex policy process followed by the CCS system in the EU. It sheds light on the relevant role played the European Commission and the European Parliament in setting the environmental standards to be respected (that is 'green Europeanization' of energy policy alternative technologies), the pressures from some member states acting as front-runners and the multilevel interactions between political and economic actors to get public financial support to private operators.

To close Part I, dedicated to the internal dimension, in Chapter 6 Israel Solorio Sandoval and Esther Zapater address the Europeanization of energy governance in the EU and the relative importance of the 'green driver' (that is the 'green Europeanization' of energy governance). Importantly in this sense, the chapter constitutes a broad picture of the institutionalization of energy policy at the European level and the predominant forms of governance in this process.

Part II, dealing with the external dimension, starts with Chapter 7 and the exploration of the marketization of energy policy in central and eastern Europe (CEE). Starting from the ill-known environmental regulatory legacy of these countries before their accession to the EU, Michael Dobbins and Jale Tosun review the marked-based instruments put in practice in CEE, showing up the differences with regard to the EU-15 (that is the limits of the EU as a 'greenenergy' model exporter towards the CEE countries). The empirical analysis is focused on the application of environmental taxes related to one particular source of energy (fuels). Dobbins and Tosun's main assumption is that 'market-based policy instruments should be more prominent in the CEE countries than in the EU-15'. The justification lies both in the regulatory legacies and the opportunity structures for environmental policy actors operating in the industrial and energy sectors.

Chapter 8 is focused on the EU's energy security issue with regard to its eastern neighbors and the southern Caucasus as the most relevant areas in terms of supply and transit of natural gas. The main research question put forward by Anna Herranz-Surrallés and Michal Natorski is about the extent to which the EU's concerns over energy security have affected its foreign policy, impacting also on other strategic areas (that is testing the role of the EU as a 'green-energy' model exporter towards the east). The analytical approach 
builds on the three dimensions of the EU's external energy relations: promoting market-oriented policies, Europeanization beyond the EU' (fostering environmental protection and RES, and combating climate change) and security of supply. The chapter illustrates the growing importance of the third dimension as a result of the strong energy dependency of the EU, exacerbated by recent disputes with Russia relating to the supply of natural gas. Particular attention is paid to bilateral relations with three strategic countries; Russia, the main supplier of hydrocarbons to the EU; Ukraine, the most important transit country for the transport of gas; and Azerbaijan, regarded as one of the alternative suppliers of natural gas via the Nabucco pipeline. The last point focuses on the recent European attempts to develop a more institutionalized cooperation framework in the region through a number of multilateral initiatives such as INOGATE-Baku and the Eastern Partnership.

Andrea Ciambra (Chapter 9) addresses the question of whether - and how - the EU's external relations policy combines its twofold strategy towards promoting competitiveness and sustainability concerns with regard to energy issues. With this aim, the study reviews, from a sociological institutionalist approach, the theoretical fundamentals of the EU's market-oriented external energy relations. Subsequently, the author identifies the instruments set up by the EU to achieve its strategic objectives. These are empirically applied to the neighboring countries in the western Balkans. Drawing on the creation of the Energy Community (EnC), Ciambra evaluates the degree of socialization achieved in this area through the penetration of the energy's acquis (that is the EU as a 'green-energy' model exporter towards the western Balkan countries). He underlines the relevance of economic and political expectations, but also the sharing of common values as explanatory variables.

In Chapter 10, Luigi Carafa turns to the EU's influence on energy sector reform in Turkey. The analytical focus draws on the transformative power of the EU in the international system and the impacts of Europeanization beyond its borders. The enlargement policy is a main driver to promote changes in the energy policy sector of candidate countries, like Turkey, that must adapt their domestic regulations to comply with the requirements of the acquis communautaire. However, the impacts of these changes are still poorly understood. The chapter examines the implementation of EU-based energy reforms in Turkey, arguing that the principle of conditionality is not sufficient by itself to explain the reforms operated in this country (that is the EU as a 'green-energy' model exporter towards Turkey). Other factors, such as the impacts of European energy Regulations together with key domestic concerns, also play a considerable role. Such a statement is empirically rooted on three case studies related, respectively, to energy competitiveness, energy security and sustainability.

As an interesting example of an experimental external European energy policy, Chapter 11 explores the efforts of the EU to foster the deployment of 
RES in the southern shore of the Mediterranean. Gonzalo Escribano-Francés and Enrique San Martín González investigate the reasons behind the launching of the Mediterranean Solar Plan, paying particular attention to the case of Morocco as the best-positioned country in the region to implement the Plan (that is the EU as a 'green-energy' model exporter towards the southern Mediterranean). In addition to the important financial and technological challenges that project entails, the discussion also revolves around two interrelated issues: the implications of the Mediterranean Solar Plan as a potential economic driver for Morocco's development and its EU-centric design tailored to the requirements of European environmental and technological priorities.

In Chapter 12, in their concluding remarks, Francesc Morata and Israel Solorio Sandoval assess the overall 'green contribution' to the construction of European energy policy and the perspectives for further research in the field.

\section{NOTES}

1. The bulk of official documents dealing with energy policy in the EU have also used the wording 'EU's energy Policy' and energy Policy for Europe'. In this volume we rely mainly on the use of 'European energy policy' as a term to refer to this emergent policy. However, the use of any one of these phrases is correct and, in any case, some authors also alternatively adopt one of the other options for referring to the subject of this book.

2. In order to trace out this process, we adopt the environmental policy integration (EPI) definition put forward by Ute Collier (1994), which regards EPI as a concept aimed at 'achieving sustainable development and preventing environmental damage; removing contradictions between policies as well as within policies; and realizing mutual benefits and the goal of making policies mutually supportive' (Collier, 1994, p. 36).

\section{REFERENCES}

Andersen, S. (1999), 'European integration and the changing paradigm of energy policy: the case of natural gas liberalization', Arena Working Papers, 99 (12), accessed 18 November 2010 at www.sv.uio.no/arena/english/research/publications/ arena-publications/workingpapers/.

Andersen, S. (2000), 'EU energy policy: interest interaction and supranational authority', Arena Working Papers, 100 (5), accessed 18 November 2010 at www.sv. uio.no/arena/english/research/publications/arena-publications/workingpapers/.

Barbé, E., O. Costa, A. Herranz Surrales and M. Natorski (2009), 'Which rules shape EU external governance? Patterns of rule selection in foreign and security policies', Journal of European Public Policy, 16 (6), 834-52.

Bartle, I. (1999), 'Transnational interests in the European Union: globalization and changing organization in the telecommunications and electricity', Journal of Common Market Studies, 37 (3), 363-83.

Bartle, I. (2002), 'When institutions no longer matter: reform of telecommunications 
and electricity in Germany, France and Britain', Journal of European Public Policy, 22 (1), 1-27.

Belyi, Andrei (2008), 'EU external energy policies: a paradox of integration', in Jan Orbie (ed.), Europe's Global Role, London: Ashgate, pp. 203-16.

Buchan, D. (2009), Energy and Climate Change: Europe at the Crossroads, Oxford: Oxford University Press.

Bulmer, Simon (2007), 'Theorizing Europeanization', in P. Graziano and V. Vink (eds), Europeanization: New Research Agendas, New York: Palgrave Macmillan, pp. $3-20$.

Caporaso, James (2007), 'The three worlds of regional integration theory', in P. Graziano and V. Vink (eds), Europeanization: New Research Agendas, New York: Palgrave Macmillan, pp. 23-34.

Collier, Ute (1994), Energy and Environment in the European Union: The Challenge of Integration, Aldershot: Avebury.

Collier, U. (1997), 'Prospects for a Sustainable Energy Policy in the European Union' European University Institute working paper, Robert Schuman Centre no. 97/29, London.

Collier, Ute (2002), 'EU energy policy in a changing climate', in A. Lenschow (ed.), Environmental Policy Integration: Greening Sectoral Policies in Europe, London: Earthscan Publications, pp. 175-92.

Commission of the European Communities (1972), Necessary Progress in Community Energy Policy, COM(72) 1200, 4 October, Supplement to Bulletin of the European Communities, no. 11.

Commission of the European Communities (1974), Towards a New Energy Policy Strategy for the European Community, Com(74) 550 final/2, Brussels, 26 June.

Council of the European Communities (1974), Council Resolution of 17 December 1974 on a Community Action Programme on the Rational Utilization of Energy, accessed 18 November 2010 at http://eur-lex.europa.eu/en/legis/latest/ chap121010.htm. .

Council of the European Communitues (1975), Council Resolution of 3 March 1975 on Energy and the Environment, accessed 18 November 2010 at http://eurlex.europa.eu/en/legis/latest/chap121010.htm.

Council of the European Union (2007), Action Plan (2007-2009): An Energy Policy for Europe, Presidency Conclusions, Brussels, 8-9 March, accessed 18 November 2010 at http://register.consilium.europa.eu/ pdf/en/07/st07/ st07224-re01.en07. pdf

Correljé, A. and C. van der Linde (2006), 'Energy supply security and geopolitics: a European perspective', Energy Policy, 34 (5), 532-43.

Damro, C., Hardie, I. and D. MacKenzie (2008), 'The EU and climate change policy: law, politics and prominence at different levels', Journal of Contemporary European Research, 4, 179-92.

Eising, R. and N. Jabko (2001), 'Moving targets: national interests and electricity liberalization in the European Union', Comparative Political Studies, 34 (7), $742-67$.

Escribano, G. (2010), 'Convergence towards differentiation: the Europeanization of Mediterranean energy corridors', Mediterranean Politics, 15 (2), 211-29.

European Commission (1998), Communication from the Commission of 14 October 1998: Strengthening Environmental Integration within Community Energy Policy, accessed 18 November 2010 at http://eur-lex.europa.eu/smartapi/cgi/sga_doc? smartapi!celexplus!prod!DocNumber\&lg=en\&type_doc=COMfinal\&an_doc=199 $8 \&$ nu_doc $=571$.

European Commission (2006), Green Paper of 8 March 2006: A European Strategy for 
Sustainable, Competitive and Secure Energy, Brussels, 8 March, accessed 18 November 2010 at http://eur-lex.europa.eu/smartapi/cgi/sga_doc?smartapi!celexplus!prod!DocNumber\&lg=en\&type_doc=COMfinal\&an_doc $=2006 \& n u \_d o c=105$

European Commission (2007), Communication from the Commission to the European Council and the European Parliament of 10 January 2007: An Energy Policy for Europe, accessed 18 November 2010 at http://eur-lex.europa.eu/smartapi/cgi/sga _doc?smartapi!celexplus!prod!DocNumber\&lg=en\&type_doc=COMfinal\&an_doc $=2007 \&$ nu_doc $=1$.

European Commission (2008), Communication from the Commission to the European Parliament, the Council, the European Economic and Social Committee and the Committee of the Regions - Second Strategic Energy Review: An EU Energy Security and Solidarity Action Plan, accessed 18 November 2010 at http://eurlex.europa.eu/LexUriServ/LexUriServ.do?uri=CELEX:52008DC0781:EN:HTML: NOT.

European Commission (2011a), Communication from the Commission to the European Parliament, the Council, the European Economic and Social Committee and the Committee of the Regions: Energy 2020: A Strategy for Competitive, Sustainable and Secure Energy, $\operatorname{COM}(2010)$ 639, Brussels.

European Commission (2011b), Background Paper: Energy Roadmap 2050 - State of Play, Brussels, 3 May.

Henningsen, J. (2008), 'EU energy and climate policy - two years on', European Policy Centre, issue paper, 55, September, Brussels.

Herranz-Surrallés, A. and E. Zapater (2010), 'A toda luz y a medio gas: relaciones energéticas entre la Unión Europea y su entorno próximo', in La Unión Europea más allá de sus fronteras ¿Hacia la transformación del Mediterráneo y Europea oriental?, Madrid: Tecnos.

Humphreys, P. and S. Padgett (2006), 'Globalization, the European Union, and domestic governance in telecoms and electricity', Governance: An International Journal of Policy Administration and Institutions, 19 (3), 383-406.

Jordan, A., R. Brouwer and E. Noble (1999), 'Innovative and responsive? A longitudinal analysis of the speed of EU environmental policy-making, 1967-97',Journal of European Public Policy, 6 (3), September, 376-98.

Jordana, J., D. Levi-Faur and I. Puig (2005), 'The limits of Europeanization: regulatory reforms in the Spanish and Portuguese telecommunications and electricity sectors', European Integration online Papers (EIOP), 9 (10), accessed 18 November 2010 at http://eiop.or.at/eiop/texte/2005-010a.htm.

Knill, C. and A. Lenschow (2005), 'Compliance, competition, and communication: different approaches of European governance and their impact on national institutions', Journal of Common Market Studies, 43 (3), 583-606.

Lavenex, S. and F. Schimmelfennig (2009), 'EU rules beyond EU borders: theorizing external governance in European politics', Journal of European Public Policy, 16 (6): 791-812.

Lavenex, Sandra and Adam Stulberg (2007), 'Connecting the neighborhood: energy and environment', in Weber, K., M.E. Smith and M. Baun (eds), Governing Europe's New Neighborhood: Partners or Periphery? Manchester: Manchester University Press, pp. 134-55.

Lenschow, A. (2002), 'Greening the European Union: an introduction', in A. Lenschow (ed.), Environmental Policy Integration: Greening Sectoral Policies in Europe, London: Earthscan Publications, pp. 3-21.

Levi-Faur, D. (2002), 'On the "net impact" of Europeanization: the EU's telecoms and 
electricity regimes between the global and the national', European Integration online Papers (EIOP), 6 (7), accessed 18 November 2010at http://eiop. or.at/eiop/texte/2002-007a.htm.

Lucas, N.J.D. (1977), Energy and the European Communities, London: Europa.

Matláry, J. (1997), Energy Policy in the European Union, New York: St Martin's Press.

McGowan, F. (2008), 'Can the European Union's market liberalism ensure energy security in a time of economic nationalism?', Journal of Contemporary European Research, 4 (2), 90-106.

Müller-Kraenner, S. (2010), 'The external relations of the EU in energy policy', European Community for Renewable Energy (ERENE), issue paper 6.

Natorski, M. and A. Herranz-Surrallés (2008) 'Securitizing moves to nowhere? The framing of the European Union's energy policy', Journal of Contemporary European Research, 4 (2), 71-89.

Oberthür, S. and M. Pallemaerts (2010), 'The EU's internal and external climate policies: an historical overview', in S. Oberthür and M. Pallemaerts (eds), The New Climate Policies of the European Union: Internal Legislation and Climate Diplomacy, Brussels: VUB Press.

Oettinger, G. (2010a), 'Energy challenges of the next ten years: the need for a European common policy', speech at the Stakeholder Conference on Preparation of Energy Strategy 2011-2020, Brussels, 30 September, accessed 18 November at http://europa.eu/rapid/pressReleasesAction.do?reference=SPEECH/10/504.

Oettinger, G. (2010b), 'Europeanization of energy policy', speech of Commissioner Oettinger at the Dinner Debate with the European Energy Forum, Strasbourg, 19 October, accessed 18 November at http://europa.eu/rapid/ pressReleasesAction. do? reference $=$ SPEECH $/ 10 / 573 \&$ format $=$ HTML\&aged $=0 \&$ language $=E N$.

Owens, S. and C.W. Hope (1989), 'Energy and environment: the challenge of integrating European policies', Energy Policy, 17 (2), 97-102.

Piebalgs, A. (2009), 'How the European Union is preparing the third industrial revolution with an innovative energy policy', EUI Working Papers, RSCAS 2009/11.

Pollack, M. (1994), 'Creeping competence: the expanding agenda of the European Community', Journal of Public Policy, 14 (2), 95-145.

Radaelli, C.M. (2000), 'Whiter Europeanization? Concept stretching and substantive change', European Integration online Papers (EIOP), 4 (8), accessed 18 November 2010 at http://eiop.or.at/eiop/texte/2000-008a.htm.

Skjaerseth, J. (1994), 'The climate policy of the EC: too hot to handle', Journal of Common Market Studies,32, (1), 25-42.

Solorio Sandoval, I. (2009), 'La construccion de la política energética europea desde el area medioambiental', in F. Morata (ed.), La Energía del siglo XXI: perspectivas europeas y tendencias globales, Barcelona: Institut Universitari d'Estudis Europeus, pp. 99-118.

Solorio Sandoval, I. (2011) 'Bridging the gap between environmental policy integration and the EU's energy policy: mapping out the "Green Europeanisation" of energy governance', Journal of Contemporary European Research, 7 (3), 396-415.

Twidell, John and Robert Brice (1992), 'Strategies for implementing renewable energy: lessons from Europe', Energy Policy, 12 (5), 464-79.

Umbach, F. (2010) 'Global energy security and the implications for the EU', Energy Policy, 38 (3), 1229-40.

Vink, M. and P. Graziano (2007), 'Challenges of a new research agenda', in P. Graziano, and V.M. Vink (eds), Europeanization: New Research Agendas, New York: Palgrave Macmillan, pp. 3-20. 
Wurzel R.K.W. and J. Connelly (eds.) (2011), The European Union as a Leader in International Climate Change Politics, New York: Routledge.

Zapater, E. (2009), 'La seguridad energética de la Unión Europea en el contexto de la nueva política energética y el tratado de Lisboa', in F. Morata (ed.), La Energía del siglo XXI: perspectivas europeas y tendencias globales, Barcelona: Institut Universitari d'Estudis Europeus, pp. 49-79. 